\title{
Family Psychic Transmission and Anorexia Nervosa
}

\author{
Élide Dęoti Valdanha-Ornelas - Universidade de São Paulo, Ribeirão Preto, Brasil \\ Manoel Antônio dos Santos - Universidade de São Paulo, Ribeirão Preto, Brasil
}

\begin{abstract}
Studies show that family relationships can act as mediating agents in triggering and maintaining the symptoms of anorexia nervosa $(\mathrm{AN})$, especially the mother-daughter relationship configuration, which contains unconscious elements transmitted inter-generationally. This study aimed to understand the role of intergenerational psychic transmission in the articulation of anorexic symptoms in a young woman in treatment. Three generations of women of the same family were interviewed: maternal grandmother, mother and daughter, all diagnosed with AN. Some psychic contents that could not be elaborated were identified in the reports and these were, subsequently, converted into legacies transmitted to later generations. Feelings of inhibition and shame regarding sexuality and the female body, transmitted from grandmother to mother and from mother to granddaughter, seem to have blocked the emotional development in all generations. Incorporating these findings into treatment may facilitate the processing of the transmitted unconscious contents, contributing to the reorganization of the family's psychodynamic functioning.

Keywords: intergenerational relations, psychic transmission between generations, eating disorders, anorexia nervosa, mother child relations
\end{abstract}

Transmissão Psíquica Familiar e Anorexia Nervosa

\begin{abstract}
Resumo
Estudos evidenciam que as relações familiares podem atuar como agentes mediadores no desencadeamento e manutenção dos sintomas de anorexia nervosa (AN), especialmente a configuração vincular mãe-filha, que contém elementos inconscientes transmitidos transgeracionalmente. Este estudo teve por objetivo compreender a implicação da transmissão psíquica transgeracional na articulação do sintoma anoréxico em uma jovem em tratamento. Foram entrevistadas mulheres de três gerações de uma mesma família: avó materna, mãe e filha (com diagnóstico de AN). Foram identificados nos relatos conteúdos psíquicos que não puderam ser elaborados e que, posteriormente, converteram-se em legados transmitidos para as gerações posteriores. Sentimentos de inibição e vergonha em relação à sexualidade e ao corpo feminino, transmitidos da avó para a mãe e desta para a neta, parecem bloquear o desenvolvimento afetivo nas gerações posteriores. Incorporar esses achados ao tratamento da neta pode facilitar a elaboração dos conteúdos inconscientes transmitidos, contribuindo para reorganização do funcionamento psicodinâmico familiar.

Palavras-chave: relação entre gerações, transmissão psíquica entre gerações, transtornos da alimentação, anorexia nervosa, relações mãe-criança
\end{abstract}

\section{Transmisión Psíquica Familiar y la Anorexia Nervosa}

\begin{abstract}
Resumen
Los estudios demuestran que las relaciones familiares pueden actuar como agentes mediadores en el desencadenamiento y mantenimiento de los síntomas de anorexia nerviosa (AN), especialmente en la configuración del vínculo entre madre e hija, que contiene elementos inconscientes transmitidos transgeneracionalmente. Este estudio tuvo como objetivo comprender la implicación de transmisión psíquica transgeneracional en la articulación de los síntomas de anorexia de una joven en tratamiento. Mujeres de tres generaciones de una misma familia fueron entrevistadas: abuela materna, madre e hija con diagnóstico de AN. Fueron identificados en los relatos, contenidos psíquicos que no pudieron ser elaborados y, posteriormente, se convirtieron en legados transmitidos para generaciones posteriores. Sentimientos de inhibición y vergüenza con relación a la sexualidad y al cuerpo femenino, transmitidos de abuela para madre y de madre para hija, parecen bloquear el desarrollo afectivo en las generaciones posteriores. Incorporar estos resultados en el tratamiento de la nieta puede facilitar la elaboración de los contenidos inconscientes transmitidos, contribuyendo para reorganizar el funcionamiento psicodinámico familiar.

Palabras-clave: relación entre generaciones, transmisión psíquica entre generaciones, problemas de alimentación, anorexia nerviosa, relaciones madre-niño
\end{abstract}

Eating disorders (EDs) constitute serious disturbances in eating behavior, of multifactorial etiology, which are considered chronic health conditions (Ribeiro \& Santos, 2013). These psychopathologies, especially anorexia nervosa (AN) and bulimia nervosa $(\mathrm{BN})$, haves become a major subject in the national and international scientific literature, due to the numerous physical, psychological, family and social compromises 
they cause, potentializing impairments in the psychological development (Leonidas \& Santos, 2014; Nilsson, Abrahamsson, Torbiornsson, \& Hägglöff, 2009; Valdanha, Scorsolini-Comin, Peres, \& Santos, 2013).

Anorexia nervosa is one of the most prevalent EDs. According to the Diagnostic and Statistical Manual of Mental Disorders - DSM-V (American Psychiatric Association, 2013), AN configures a clinical condition characterized by the refusal of an individual to maintain his/her body weight above the normal minimally expected for the age and height, plus the intense fear of gaining weight and the presence of severe body image distortion, which result in cachexia (severe weakness of the body) and poor bodily posture resulting from severe malnutrition (Claudino \& Borges, 2002; Klump, Bulik, Kaye, Treasure, \& Tyson, 2009). In addition, this disorder leads to a drastic reduction in the quality of life (Oliveira-Cardoso, Von Zuben, \& Santos, 2014), with studies considering $\mathrm{AN}$ to be the psychiatric disorder with the highest mortality rate (Birmingham Su, Hlynsky, Goldner, \& Gao, 2005; Klump et al., 2009; Morgan \& Claudino, 2005).

In this context, the cult of the slim figure and the imperative of the uninterrupted preservation of youth are expressions of society's obsession with the pursuit of eternal life. The individuals learn that they must restrict their diet and give up the pleasure derived from food in order to correspond to the valorized standards of health and beauty that currently prevail (Miranda, $2007,2011)$. There is a migration of internal problems to the body, which is used as a means of expression for suffering that is clearly difficult to manifest in psychic terms (Fernandes, 2003).

The refusal to eat, observed in patients with AN can be considered a defense that reflects an attempt to contain the anguish of separation and to stanch their feelings of helplessness and abandonment. Thus patients seek to defend a state of disorganization and fragmentation of the self that haunts them all the time. Gaining weight would demonstrate a failure of self-discipline, which becomes unacceptable for the controlling and perfectionist patients (Gaspar, 2005; Lawrence, 2002). Therefore, weight loss is felt to be a conquest, to be a sign of maintaining self-control (Brusset, 2008; Valdanha, Oliveira-Cardoso, Ribeiro, Miasso, Pilon, \& Santos, 2014).

Despite the severity of the condition of some young people with EDs, it is clear that many families are reluctant to accept the diagnosis and monitor their children during the treatment (Souza \& Santos, 2012).
The literature devoted to investigating the families of individuals affected by EDs shows that the family relationships are largely dysfunctional, with controlling mothers and absent or frail fathers (Perkins, Slane, \& Klump, 2013; Tuval-Mashiach, Hasson-Ohayon, \& Ilan, 2014). The majority of cases present recurring traumas, turbulent relationships and interpersonal conflicts that compromise the family dynamics (Cao, Miao, \& Tong, 2013; Leonidas \& Santos, 2014; Marcos \& Cantero, 2009). In addition, the parents intensely display attempts to control children with EDs, limiting their autonomy and providing little encouragement for the development of their personal resources (Chan \& Ma, 2004; Latzer, Lavee, \& Gal, 2009).

Transitional stages of the family life cycle, such as adolescence, often constitute challenging phases, which can increase vulnerability (Goulart \& Santos, 2012). This is more worrying when these phases are permeated by a lack of support from the parental figures, which may influence the expression of abnormal eating behaviors, constituting potential risk factors for the onset and maintenance of ED symptoms (Andrade \& Santos, 2009; Canetti, Kanyas, Lerer, Latzer, \& Bachar, 2008; Rosa \& Santos, 2011; Valdanha, ScorsoliniComin, Peres, \& Santos, 2013).

Some life events can potentialize this vulnerability, such as the death of a family member, drastic changes in the pattern of relationships (as in a divorce and/or remarriage of a parent), change of school, home or job, chronic illness and/or prolonged hospitalization, and sexual abuse (Berge, Loth, Hanson, Croll-Lampert, \& Neumark-Sztainer, 2011; Ma, 2005, 2008). However, the destabilizing potential of stressful events depends on the configuration and effectiveness of the social support network, which can either serve as a protective factor or as a factor of vulnerabilization (Leonidas \& Santos, 2013; Leonidas, Crepaldi, \& Santos, 2013).

The theoretical and conceptual framework that underlies this study is psychoanalysis, more specifically the theory of intergenerational psychic transmission. This theory outlines a field of unconscious psychic forces, which result from the reiterated work of successive generations. Eiguer (1985), one of the main theorists of this approach, presented a new concept of the family group, in which the individual psyches together form a collective, which he designated as the unconscious organizer of the family life. Thus, it can be said that the family organization is composed of individuals who, as a group, present an unconscious psychic functioning different from its isolated functioning. 
According to this author, the family organizer has a direct impact on the consolidation of bonds established within the family group.

When a couple conceives a child, a new family group is structured, which establishes an imaginary that will be experienced by the generations to come. This scenario serves as support for the entry of the subject into the history, along with their position in the difference between the sexes and generations, which creates experiences of being loved and recognized in their family nucleus of origin. The family carries with it content of previous generations, so that the child is the target of expectations both of its parents and of the preceding generations (Bertin \& Passos, 2003). On the other hand, the arrival of the child modifies the couple, transforming them and leading to the transition to assume the parental roles. In this process of transition and appropriation of new functions and family roles, the conjugal nucleus expands, forming a family. Diverse dynamics are then articulated that reorganize the psychic economy of the couple and engender the bonds between the family members (Correa, 2000).

In constructing a new family, Almeida (2010) highlights the intersection of paternal and maternal lineages, which put in motion both identifications and counter-identifications. This process mobilizes intense forces of love and hate, which coalesce around what is accepted and also what is denied and concealed, making it impossible to rationally control all that is transmitted in the intergenerational psychic chain. Regarding the intergenerationality, according to Kaës (2001) and Benghozi (2010), what is mobilized intergenerationally is what was psychically transmitted without being properly symbolized, which makes its subsequent reworking impossible, both for the family, as well as for the individual receiving the legacy.

According to Soifer (1980) there is no "symptomatic" patient, but a psychodynamic functioning that happens and involves the entire family, who do not realize what they are transmitting and the way they pass along the received legacy. The person who becomes ill is often the one that, in terms of the unconscious family life, denounces the latent conflicts that could not be unraveled and elaborated by the entire family group. The problem is that the family does not perceive this implication, due to the effects of repression or denial. For this reason the symptom is seen with alienation and total perplexity. According to this theoretical concept, the child repeats the non-symbolized history of the parental figure with whom he/she identifies, in a failed attempt to process what could not be elaborated by the previous generations. As this repeated content remains inaccessible to symbolization, the symptom tends to perpetuate itself, installing a deadly cycle that impoverishes not only the one who is directly affected, but also the rest of the family, which somehow remains stagnant in a paralyzing dynamic.

Considering these assumptions, this study aimed to comprehend the implication of intergenerational psychic transmission in the articulation of the anorexic symptoms in a young woman undergoing treatment.

\section{Method}

This was an exploratory, descriptive and crosssectional study, with a qualitative approach, based on the theoretical framework of intergenerational psychic transmission (Eiguer, 1985; Kaës, 2001). The case study design was chosen, which proposes a focused investigation into a single case, in order to comprehend in depth important characteristics of real life events (Stake, 2000). According to Yin (2005), the case study can be used to describe a situation, such as the intervention or the real-life context in which the events occur. In the present study the maternal lineage (three generations) of the family of a patient diagnosed with $\mathrm{AN}$ was selected as the case to be investigated. The choice of the case took place in a universe of six families investigated, of which one was selected, here called de Azevedo family, due to being the one that best showed the elements of intergenerational psychic transmission.

\section{Participants}

Three women of the Azevedo family were interviewed. All the names used in this study are fictitious, in order to preserve the identity of the participants. Those included were: Mabel, 25, married, with a diagnosis of AN; her mother, Alba, 51, married, and her maternal grandmother, Carmosina, 87, widowed. The participants were included according to the following criteria: patient with a confirmed diagnosis of AN (restrictive or purgative subtype) according to the DSM-V; having a mother and maternal grandmother capable of responding to the interview.

\section{Instruments}

For the data collection three semi-structured interview scripts were used, adjusted for each participant according to the generation in which the participant belonged. The scripts addressed issues related to 
childhood, adolescence and other stages of development of each participant, emphasizing the transition steps (entry into adulthood and marriage, for example), family relationships, care of the offspring (for grandmother and mother only), of the body and eating. The interviews were of 50 -minute average duration.

\section{Procedures}

The interviews with the grandmother and mother were carried out in their homes, at the convenience of the participants. The interview with the patient was performed in a private room of the health service. Being in the homes of the families allowed access to some information derived from observation of the domestic environment, which promoted better comprehension of the case investigated.

The reports produced by the three participants were organized using the thematic content analysis method (Bogdan \& Biklen, 1994), and analyzed according to the psychoanalytical theoretical framework of intergenerational psychic transmission. This analysis procedure allowed the construction of six thematic categories that directly corresponded with the questions formulated in the interview scripts, which will be presented and discussed below in order to highlight the intergenerational psychic transmission processes in the Azevedo family.

The research project was approved by the Research Ethics Committee (Process: CEP-FFCLRP No. 567/2011 - 2011.1.1035.59.5). All the participants consented to participate in the study, through the formalization of the agreement by signing the Terms of Consent.

\section{Results and Discussion}

\section{Striking Moments of Childhood and Adolescence}

Carmosina related having few memories from her childhood and adolescence. She reported the memory of having had a very angry mother, in contrast to a loving father, described as a poor man. She was one of seven siblings (Carmosina, two sisters and four brothers) and they all lived on a cotton farm, until the siblings were married and gradually ceased living in the countryside.

Alba also highlighted, among the memories of her childhood, the memories of the parental figures. She recalled that her father was always a man of strict principles, however, affectionate. She felt very cared for by him, attributing this experience to the fact that there were nine siblings with only two being women (her and one sister). The daughters were pampered by the father, while the mother was always more severe and cold. In her adolescence, Alba worked to help to sustain the home, however, resented the need to give all the salary she received at the end of the month to her father, who controlled their finances. After her marriage she stopped working and began to be economically dependent on her husband, which also bothered her because she wanted to have financial independence.

Mabel reported not remembering many experiences from her childhood. When she began school activities she faced many difficulties in adapting. She recalled that she wept a lot when it was time to go to school. At that time she already showed indications of difficulty in separating from the family and always avoided being away from home. She reported that she was a "greedy" child and was constantly reprimanded by older people, saying that she should stop eating sweets. With intense discomfort she remembered that she was called derogatory nicknames by her peers that alluded to her being overweight, which for her marked a humiliating experience and moral condemnation. There is abundant evidence in the literature that comments on weight made by family and friends during childhood and adolescence significantly increases the risk of developing EDs (Eisenberg, Berge, Fulkerson, \& Newmark-Sztainer, 2012; Field et al., 2008; Honey, Halse, Kohn, \& Madden, 2006; Keery, Boutelle, Berg, $\&$ Thompson, 2005).

In the reports of Mabel regarding her adolescence, it was impossible to separate her memories of the symptoms of $\mathrm{AN}$, as she considered them inseparable from her development after puberty. She stated that she felt that she "jumped" a stage of life:

Because, at 13 years, to almost 14, that's when I started to
get sick, so I didn't have that thing of going out of the house
much. I lived my teenage years in the hospital, being
treated, or at home. It was that anguish, I mean, I was living
in my world, but it was a world that was heavy for me,
and I do not know why I lived in it there. (Mabel, daughter,
aged 25 years)

Mabel said that she lost the bonds with loved ones at this time, due to changing city, and because she did not know how to deal with these emotional disruptions. Significant changes in the family life may also have contributed to the outbreak of the ED condition (Berge et al., 2011; Ma, 2005, 2008). For Eiguer (1985), some families experience every kind of separation with intense pain, without the capacity 
for the elaboration of grief. In the family in question, the difficulties experienced seem to have built up and triggered a crisis, reinforcing only dominant ideas of failure, pessimism and fear about the future projected as unsatisfactory. In the family of Mabel, the reports of losses and breaking of emotional bonds in childhood and youth also permeate the reports of the women who represent the successive generations. The blocks generated by traumatic events appear to slow the development of the individuation process, locking the movements of the pursuit of autonomy, thus compromising the dynamics of the family life cycle (Onnis, Gianuzzi, \& Romano, 2007).

\section{Relationships with the Parents}

Reinforcing what had already been established by her grandmother in the accounts of her childhood and adolescence, Carmosina was also unable to clarify what her relationship with her parents was like. She merely reiterated in her account, the image of a strong, authoritarian mother, and outlined the father as a fragile man, obedient to the orders of her mother, showing in the generation of the grandmother a familiar functioning characteristic that is typical of families of people diagnosed with EDs (Perkins et al., 2013; Tuval-Mashiach et al., 2014), noting that the symptoms emerged in a representative of the third generation.

Alba, when talking about her relationship with her parents, repeated the story of Carmosina, highlighting the reproduction of certain patterns in the psychic representation of the family functions and roles. According to Wagner (2004), the family nucleus is structured on what was transmitted, seeking a repetition of the family ideology, which consists of the legacies received. The mother of Alba was perceived as an angry lady, very demanding and a perfectionist in carrying out the duties of the home, which meant that Alba and her sister learned domestic activities really well. The introjection of a rigid superego translates into characteristics such as determination, stubbornness and perfectionism, which will be transferred to the symptoms of $\mathrm{AN}$.

The relationship with the parental couple, in the report of Mabel, indicates that her father was "quieter" than her mother, less concerned with the eating of his daughter, concentrating more on other areas of her life. Meanwhile, her mother was shown to be excessively vigilant and interested in every step taken by her daughter in her daily life, trying to keep her under strict control and monitoring. Mabel felt that she could not share her day-to-day problems with her mother, which tends to maximize the conflicts instead of offering continence. Thus, family micro-secrets will be constructed, which constitute a type of family functioning permeated by mysteries and distrust in the interpersonal relationships (Wagner \& Falcke, 2004).

\section{Affective-Sexual Development and Loving Relationships}

Carmosina said that she felt much shame every time she told her husband that she was pregnant, attributing this experience to the fact of being "from the countryside". Her female body seemed packed in secrets and puzzles that were not unraveled, which could not be genuinely experienced by her and precluded any communication involving body size. Sexuality was shrouded in an aura of mystery and modesty.

Alba says she met her husband at a dance club. They experienced a period of courtship, perceived by her as very short (about one year) and serious, with times of going out and arriving home strictly controlled by her father. They married in a religious ceremony, surrounded by rumors that Alba was pregnant, due to the early marriage. The mysteries related to the body and pregnancy were increasing and perpetuating over time.

The first year of married life was described by her as the most difficult. She felt that, by leaving home, she lost the special attention of her father. The main marital crises were caused by financial issues or happened due to raising children. She felt that her husband was absent in the family life, but proved to be a good father, however, with few opportunities to speak with her and the children. The diagnosis of AN of Mabel in adolescence showed the existence of many previous conflicts within the family nucleus and in the conjugal relationship of Alba and her husband.

She got sick and he [busband] did not accept her illness at all, the family also did not accept it, so it took a year just for us to accept her treatment with a psychiatrist, during which she got worse [...] Then our marriage almost ended even when she was admitted to the [bospital]. She was there for four months, right. [Alba stayed with her daughter throughout the period of hospitalization]. So it was when we came back, that was when we were a bit excluded, you know? They did not really accept us, we started to withdraw from them as well. (Alba, mother, aged 51 years)

Mabel said that her marriage was the result of a very short courtship (under 10 months), coming after the breakup of a four-year relationship. She reported that they married quickly, as her parents did, showing 
the repetition of loving relationship patterns (Eiguer, 1985). The mother, Alba, resented the situation, being hurt by how quickly the relationship unfolded. Mabel said that the first month of her marriage was complete sadness, since the mother saw the conjugal union as a betrayal perpetrated by the daughter. It therefore appears that the bonds of intense emotional dependence existing between mother and daughter with AN did not allowed the encouragement of the emancipation attempts necessary for the establishment of autonomy (Lane, 2002; Oliveira-Cardoso \& Santos, 2012; Peres \& Santos, 2011), with this separation being felt as an expression of betrayal rather than an inherent necessity in the course of development.

Mabel felt that she frightened her parents with the speed of the union, as before she was extremely dependent on them, "like a little baby" that could not survive without receiving care, and then abruptly informed them of the news, without hesitation, that she would marry. At the same time, she obtained financial independence, as she graduated, managed to get a job and started to receive her own salary. It is interesting to remember that Mabel's mother resented the fact that she worked a lot and, despite her efforts, did not achieve financial independence at a young age.

Regarding sexuality, women diagnosed with serious eating disorders tend to present problems in the emotional-sexual life, with few relationships, or relationships permeated by intense conflicts (Kaplan, 2002; Ribeiro \& Santos, 2013). Furthermore, in general they do not identify with their own bodies, rejecting the development of feminine shapes and curves. Therefore, they try to erase any traces of female sexuality from the surface of the body (Lawrence, 2002). This is evident in the cultivation of the wasted body, which allows the concealment of the phenotype marked by curves that are accentuated in adolescence, as well as the distinct shape of the breasts. In the presentation of AN patients opaque skin, possibly covered with lanugo, protruding bones and a lack of fleshly "stuffing" are highlighted, which makes the appearance less seductive and the physical traits more angular and less delicate.

\section{The Experiences of the Body and the Eating Habits}

With regard to food, Carmosina said that the family produced the foods that they consumed on the farm where they lived. In addition to subsistence agriculture, the family members were devoted to raising livestock, such as chickens and pigs. Carmosina was the only one among her siblings who did not work in the fields, as, being the oldest daughter, she had the obligation to take care of her younger brothers and sisters and to help her mother with the household chores. Currently, her home is still the family meeting point on special dates, such as Christmas and Easter. Regarding the experiences of her own body, she reported that she never had the desire to lose weight, however, she always considered herself "very thin and skinny".

Alba reported that her father had always been responsible for doing the monthly shopping, while her mother prepared the meals. Her siblings took their meals in the field, in the break between periods of hard work. The only meal experienced by the entire family group happened at Christmas, as required by Alba's father. As mentioned by Carmosina, to this day the family follows the tradition established by her father in relation to the Christmas supper. Currently, in Alba's house, it is her husband who does the household shopping, occupying a role she recognizes as masculine. She is tasked with preparing the meals, especially at dinner time, when everyone is together, since at lunchtime everyone is away from home, fulfilling their professional obligations. It is interesting to note that Alba also engaged in a remunerated activity as a cook, an activity linked to the question of feeding.

Alba said that she had a preference for savory foods. She loved to make candy, however, stated "I do not put a sweet in my mouth". She did not define why she was not attracted to candies, she just said that she could not eat them. Regarding the experiences of her own body, she said that she felt a desire to have breast implants to reduce the discomfort she felt about having small breasts. She said she had wanted to lose weight in her youth, when she had her children: She did not diet, but controlled her eating. She used clothes and other methods that disguised the extra weight she had gained during her pregnancies. Thus, Mabel's mother showed some fears and concerns in relation to weight gain, associated with body size and the excessive calories some foods that she prepared with obvious delight, such as the candies.

Concerning the eating habits, when asked who prepared the meals in her home, Mabel reported that her mother had this role, evidencing difficulty in accepting that now she had her own home and that she was constructing her family together with her partner. Regarding the mealtime, she said that the family never had the habit of sharing the table, even if all the members were at home. Being gathered together at the table to share meals was not part of the family experience. 
The literature indicates that the habit of having meals at set times and as a family helps the child realize and internalize this moment of commensality as positive, which reduces the risk of EDs (Férnandez-Aranda et al., 2006; Franko, Thompson, Barton, Affenito, \& Striegel-Moore, 2008). It is possible to perceive that to share this moment of dining was a difficulty in the Azevedo family.

Currently, in her new home, Mabel cooks for herself and her husband. She reported that she could not eat rice and beans when she was alone or anxious about work, which decreased the amount of servings eaten at meals. Her attitude concerning food seemed to be directly related to her emotional state. She needed an external requirement to eat adequately, evidencing the lack of internal limit, so that she could take responsibility for this herself without "someone else watching" or supervising her eating habits.

Regarding the perception of the body, Mabel said that she did not feel satisfied, however, reported that she could control her impulses and eat enough so that she could live properly. She felt her main vice was the abuse of laxatives, which she perceived as a compulsion:

I'm not satisfied, you know, but I will not lie, when I saw that I had lost a little weight, I was happy, but at the same time I also know what point I can get to, because if I pass that point, I know I lose control, you know. I used laxatives a lot, for a long, long time, laxatives, like this. It was this year that I managed to stop, but it's something I can not be in contact with, it is like being a junkie, because if I put one in my mouth I will not be able to stop again. And so it was something that I fought for 11 years to be able to stop. (Mabel, daughter, 25 years)

The fact that the person with AN has difficulties in facing and positively incorporating the physical and psychological changes that begin in adolescence appears as a recurring pattern in the literature (Bruch, 1973; Leonidas \& Santos, 2012; Scorsolini-Comin \& Santos, 2012). In the omnipotent attempt to halt the process of growth and differentiation in relation to the maternal body, the person would seek refuge in a squalid, emaciated body, which dramatically expresses their impossibility to enter adulthood (Gaspar, 2005). While this is a blatant expression of the person's physical weakness, this body is taken as a symbol of resistance, considering that, to radically reject the food, the patient seeks to reaffirm their threatened autonomy.

The unspoken and prohibited seem to be concentrated around the female body of the Azevedo family.
The body is experienced as a taboo, surrounded by secrets and modesty that block the possibility of conversation, as evidenced in the report of Alba:

\begin{abstract}
All that we learned, like, the first time I menstruated, I knew nothing. Because she [mother] always was, I think because of her up bringing, right, it was like that, so she did not allow us to speak about anything, she was taking birth control pills, but we could not see her take them. I remember when my three brothers were born, the last ones, I remember her pregnant, even the outfit she used when she went to the hospital with my youngest brother I remember: a pink check dress. But you could not speak about it, could not raise the issue of her being pregnant, expecting a child. (Alba, mother, 51 years)
\end{abstract}

For Onnis, Gianuzzi and Romano (2007), the secret is considered pathological when it blocks the development of the family group. For the women of the Azevedo family, to experience the body with pleasure was not a permitted experience, which makes the conversations about the topic illegitimate. The experience of motherhood was disassociated from the female identity. Alba reported having experienced many situations of suffering until she could comprehend the body that actually belonged to her, a body with erotic functions and with the ability to generate a new life, or a body moved by gestures and mechanical acts that uninterruptedly produce a force of alienated labor.

It was the father who accompanied Alba to buy clothes, which appears to be a field that could have made the creation of an experience of female intimacy possible between mother and daughter. She simultaneously perceived herself as an inheritor and a prisoner of the emotional detachment of the mother figure, as she felt that the relationship with her children, in many instances, was also permeated by absence and emotional withdrawal.

\section{Vicissitudes of the Mother-Danghter Relationship}

The octogenarian Carmosina described the relationship between her and Alba as peaceful. For her, Alba was a good daughter, she never caused her problems because she was "controlled". She does not have memories of the pregnancy, when she expected her daughter. She said that she chose her name when she read it in a magazine. They lived very close and Carmosina said that her daughter visited every day, if only for a few minutes. However Alba, in her interview, did not confirm this regularity of visits. She said that she saw her mother only once a week, which highlights 
inconsistencies in the reports obtained. This appears to reflect the inconsistencies of the family stories (Eiguer, 1985; Leonidas \& Santos, 2015) or can also indicate a situation of social desirability.

Regarding the relationship with her mother, Alba defined her as a demanding woman in relation to the responsibilities delegated to her daughters, while avoiding intimacy in the emotional and intimate contact. With her own daughter, Alba felt she owed something to Mabel, and to make up for this "lack" gave her a lot of attention after the development of the AN, while the other children were eventually neglected in relation to maternal care.

In her report, Alba said that she was "sucked dry by the anorexic, manipulative danghter", at the time that Mabel had acute symptoms of the disorder, demonstrating the ambivalence between the symbiosis and the repulsion, as while she felt manipulated, she could not be separated from her daughter (Ribeiro, 2011). She also resented being with the children on the weekends (during the long period that Mabel was hospitalized, when she spent weeks with her daughter and returned to the home only on weekends), because all the time was taken up washing and ironing the clothes and, therefore, she could not genuinely be with them, maintaining emotional exchanges. Thus, the relationship of Alba and Mabel circumscribes a field of forces outlined by ambivalent and unstable feelings, alternating between love and hate in a matter of seconds. Conversely, mother and daughter felt incomplete and empty when they were away from each other, however, they felt completely invaded and dominated when together, which corroborates the literature regarding the affective bonds in anorexia (Ribeiro, 2011).

\section{Facing the Anorexia Nervosa: From the Discovery to the Treatment}

The reports obtained show that, with the emergence of Mabel's symptoms, the family reorganized its relational dynamics, which is consistent with that reported in the literature (Eisler, 1995; Leonidas \& Santos, 2014; Ma, 2005).

For the grandmother, Carmosina, the AN of her granddaughter Mabel was "a mystery". She said that she was aware that Mabel was undergoing treatment, however, did not know exactly for which disease. She mentioned a period of acute difficulty in the life of her granddaughter, who came "close to death", however, reported not knowing whether what precipitated this situation was related to the current problem of her granddaughter, which she became aware of only when Mabel was hospitalized. The body (erogenous, biological, field of sensations, pleasure and pain) appeared to be a taboo for Carmosina, limited to an outline of secrets and unfathomable mysteries, and subject to regulations, with marks of power and modesty. Due to the interdictions, she could not talk about bodily functions or certain diseases that "mysteriously" establish themselves in the domains of the body.

Alba experienced the beginning of her daughter's anorexia, as Mabel lived with her for 14 years. The participant reported the visits to the psychiatrists of the city (as well as psychologist, nutritionist and dentist) to find a professional to give a proper diagnosis of the problem and prescribe the appropriate treatment. After the diagnosis, the family still experienced the psychiatric hospitalizations of Mabel, motivated by the deterioration of her nutritional situation, accompanied by psychic decompensation.

Regarding the possible "causes" of the AN, Alba associated the development of the symptoms with a boy with whom Mabel had been involved in their adolescence, who told her that men were not interested in fat women. The boy broke off the relationship with her at a certain point, and Alba believed that her daughter internalized the sentence and was afraid that she was fat, starting some eating restriction behaviors.

As the interview unfolded, Alba showed that she had a deeper understanding of Mabel's disease, when she went back to the beginning of her development. Thus, it is necessary here to recall the history of the pregnancy, breastfeeding and early care of Mabel.

When Alba discovered that she was pregnant with Mabel, her and her husband were going through a turbulent period of financial crisis, which put pressure on the marital relationship, as the unfavorable situation triggered frequent arguments and fights. Her husband believed Alba became pregnant on purpose and the couple experienced a period of intense emotional turmoil. Mabel was born prematurely (in the eighth month of the pregnancy), as she presented symptoms of tachycardia in the womb. From birth she showed signs of being an anxious and agitated baby, and was born in a turbulent environment in which the intense emotions could not be fully expressed or elaborated.

The baby needed to remain in hospital for a few days under intensive care. It was the grandfather (father of Alba) that took the mother to breastfeed the baby at set intervals. He unwrapped the blankets and clothes from Mabel and inspected the bracelet, to make sure she 
had not been exchanged for another baby. The grandfather seemed sensitive to the family emotions and showed a fear that his granddaughter was not wanted or well cared for. The name "Mabel" was chosen by the sister, who said, when visiting her in the hospital: "This ugly baby will be called Mabel".

At one month of age Mabel presented, according to the account of her mother, symptoms that her mother interpreted as signs of "early adolescence", such as vaginal hair and discharge. The collection of blood and other tests were required to see what was happening. At that time, the husband of Alba expressed guilt for not having wanted the pregnancy, fearing that he had passed these emotions to his daughter, worrying that the rejection could have generated these bodily dysfunctions. From this episode, the couple, especially Alba, seem to have decided that Mabel would want for nothing, and she began to receive special attention and be more cared for and spoiled than the other children.

As an adolescent, after the start of Mabel's treatment, the family went through another period of intense difficulties, with her hospitalizations and repeated relapses. One day, Mabel ingested a liter of disinfectant. In a group where there was no permeability to the dialogue and in which the expression of emotions was restrained, it is possible to see the tensions that underlay the day to day contact, with Mabel being the one that best showed that something was wrong. It can be conjectured that this child was chosen as the scapegoat for the family conflicts and problems, allowing other members to divert their attention and to channel their energies into her, disregarding their own difficulties (Oliveira \& Hutz, 2008).

According to Eiguer (1985), the psychotic symptom revealed may be the chance of "salvation" for the group, which can then seek outside help for its conflicts. Alba revealed having a certain perception that the $\mathrm{AN}$ was an unintentional way that her daughter found to draw the attention of the familiar members to some unresolved issues.

Mabel had a problem with her uterus, which Alba associated with the lack of menstruation. As a result of this, she did not know whether her daughter could have children. There seems to be fear that her daughter may not be biologically capable of experiencing motherhood, so there would be an interruption in the generational chain, considering that Alba was the eldest in her family and had been responsible, from an early age, for caring for her baby siblings.
Also for Mabel, the AN appeared as a central event of her narratives and filled practically all the contact established with the interviewer. It was therefore difficult to sort the story of Mabel into categories, because they were constantly mixed with the AN. She reported that, as an adolescent, she felt an emptiness that troubled her. She started treatment for the disorder at 14 years of age and was soon hospitalized, because she had a cardiac arrest and went into a coma for a few days. This episode did not appear in the account of the mother. In this period, Mabel seemed to live a 'foretold death', with her father buying a plot in the cemetery because of the prediction of her death or serious bodily sequelae. After coming out of the coma, Mabel told of this experience, perceived as a rebirth, as when she regained consciousness she could not speak (just babbled phrases) or walk. She felt she had to relearn these basic skills. She spent seven months in an integral hospitalization regime, unhappy at being in a psychiatric ward because she was "not crazy". In her mother's report, the hospital stay was limited to four months.

The full-time presence of a companion was required during the prolonged hospitalization. The participant said that the presence of her mother was also required, refusing to allow other people to be with her:

And so, I had a relationship a lot like, that I wanted my mother to stay with me all the time. At the same time that I wanted her close, I was angry too, you know? You know, sometimes I thought that it was her fault that I was like that, you know, a bit. And on weekends my father would also stay there with me, but I had weekends that I wanted him to be there, but I was angry that my mother was not there. It seems that it was a punishment that I had and that she also had to have. My brothers and sisters, well, they never visited me during the time that I was hospitalized, they never went there. (Mabel, daughter, 25 years)

Regarding the intense dietary restrictions observed in $\mathrm{AN}$, the tenacity in not eating can be considered a pathological stubbornness, which should be analyzed in two ways: the denial of food as an affirmation of the unconscious desire of the adolescent to separate herself from the symbiotic fusion with the mother, or as a radical attempt to annihilate this desire for separation and individuation, a situation in which the patient would be serving the internalized ideal object (mother). The intensity of the resistance of the patient, highlighted in the persistence of the symptoms, would be proportional to the level of invasion experienced by her (Fortes, 2011). The 
mother-daughter relationship in this field always presents itself as intense and ambivalent, with the feelings of love and hatred mixing and mingling all the time (Ribeiro, 2011). These vicissitudes in the bond seem to be reproduced dramatically in the patient-health professional relationship, creating challenges for the treatment (Souza \& Santos, 2013a, 2013b).

Mabel presented herself as a rebellious patient, since she did not follow the orders of the professionals who took care of her. She withdrew the probes that they inserted to provide the special diet and she stated that did not want to get better. She felt guilty because her father had suffered financially in order to cover the costs of the medical treatment at the time, which is reflected until today. She said that it was through means of a rational reflection that she chose to get better, as she was the only patient who did not receive permission to spend the weekend at home. Therefore, she started to submit and comply with the treatment requirements.

When she began an undergraduate course and moved from the city, she stated that she gained over 20 kilos, and attributes this significant weight gain to the hormone replacement she had to have at the time. She really felt the absence of her mother, since she could not make meals if she was not with her. She said that Alba also became sick because of the separation. Mabel's father had to intervene and be firm in the situation, so that his daughter did not return home and, therefore, could continue her studies. Mabel showed extreme gratitude for her father taking such a strict stance at that time. This suggests that the inclusion of the father figure, when exercising his function to prohibit and regulate instinctual impulses, favors conditions that allow organization of the conflict.

From the perception of the young woman interviewed, the family conflicts were solved with difficulty. Mabel said that she had been more explosive, however, realized that she did not succeed in her demands. Currently, she maintains a contained posture and remains silent faced with the problems and dislikes experienced within the family circle.

Mabel felt that the main problem of the family nucleus was, and still is, her eating disorder. Unlike her previous report, she said she had suffered episodes of physical abuse from her parents, in order to force her to eat, which demonstrated a comprehension of the problem as the result of a "lack of embarrassment", suggesting a rigidity that distanced them from a proper comprehension of the emotional aspects involved in AN (Valdanha et al., 2014). She considered her parents to be caught in a desperate situation, where they sought any method for their daughter to improve her symptoms. From the reports, it can be inferred that there seems to be space in the home environment for the recognition of an individualized mental world, capable of producing symptoms that are not under the conscious control of the affected member. In this context, moral and judgmental attitudes are prevalent, with the common posture being to "proportion blame" for the adverse situations.

Mabel again started to seek specialized care for ED treatment when she lived alone, in the city where she did her university studies. She reported a recurrence of some symptoms of the disorder, such as the addiction to laxatives, which meant that she walked around the city in search of different pharmacies to buy medicine because she was ashamed to think what she would be found out if she always used the same one.

An acquaintance told her of the specialized treatment. The approach to the service was spontaneous. Mabel felt that the start of treatment was very difficult, because the family believed that her symptoms had gone and that the problem would not return after years of apparent control. Despite the surprise when they learned of the relapse, her parents agreed to restart the treatment, organizing themselves to accompany her. Mabel realizes that, currently, she manages to be more rational and to distance herself, as far as possible, from her fantasies regarding food, better controlling her food and her eating habits with the support of the treatment.

\section{Final Considerations}

This case study achieved the aim proposed of comprehending some of the implications of intergenerational psychic transmission in the structuring of anorexic symptoms. From the reports obtained, it can be postulated that the dysfunctional family relationships in the Azevedo family are colored by psychic contents that were passed between generations without undergoing the necessary transformations for their proper psychic elaboration. Such contents found, in the anorexic symptom, a radicalized form of expression for the resulting discomfort of unresolved conflicts by means of sublimation. Contents related to experiences of the female body were transmitted in the intergenerational chain, with no possibility of finding continence in a genuine and transforming experience. Thus, the psychic representations engendered regarding the body, sexuality and eating constitute an uncomfortable 
inheritance permeated by secrets in the generations of women.

The mother-daughter bond proved to be ambivalent, permeated by feelings of invasion and emotional intrusion, but also by feelings of abandonment and helplessness. There are reports of repeated experiences of little affective care between mothers and daughters, forcing the daughters to disassociate the bodily satisfaction of instinctual gratification.

Evidently, it can not be said that intergenerational inheritance "causes" the ED symptoms, as the factors related to the pathogenesis of the disorder are multiple. It is in the link between what has been passed down from previous generations and the current experiences of the family that can allow the symptom to emerge as an emissary of mental suffering, related to the resonances between past and present (Onnis et al., 2007; Valdanha, Scorsolini-Comin, \& Santos, 2013).

With this case study it is possible to observed that, over the course of the treatment and with the gradual improvement of the symptoms of $\mathrm{AN}$, the body is no longer the target of intense rejection and therefore can be accepted without the desire for radical changes in the weight and body structure. The results suggest that it gradually becomes possible to be connected to the body in a healthy manner, which allows the patient to properly perceive the symptoms of the disease, as well as a feeling of a strong and bealtby body. The obsessive preoccupation with weight may become less prominent, the body can lose its place of centrality in the self-evaluation of the patient. Thus, the emotions seem to gain space, finally being recognized and experienced in a genuine way (Björk \& Ahlstrom, 2008; Noordenbos \& Seubring, 2006).

The conscientization of the psychic transmission processes allows the individual to construct a different reality, rather than repeat it unconsciously like the previous generations, thus breaking the cycle that perpetuates intergenerational legacies. In this sense, the treatment, which covers the family and not just the identified patient, serves to reveal the secret, so that everyone is aware of the situation (Wagner \& Falcke, 2004). In this promising context, a new image of the body can be forged in the relational space, together with the ability to put it into words, making it representable. The outline of a symbolized body emerges, which promotes the development of ego boundaries, from the construction of a place that contains the authentic intimate relationships.

\section{References}

Almeida, M. E. S. (2010). Uma proposta sobre a transgeracionalidade: O absoluto. Ágora, 13(1), 93-108.

American Psychiatric Association (2013). Diagnostic and statistical manual of eating disorders ( $5^{\text {th }}$ ed.). Arlington, VA: American Psychiatric Publishing.

Andrade, T. F., \& Santos, M. A. (2009). A experiência corporal de um adolescente com transtorno alimentar. Revista Latinoamericana de Psicopatologia Fundamental, São Paulo, 12(3), 454-468.

Benghozi, P. (2010). Malhagem, filiação e afiliação - Psicanálise dos vinculos: Casal, família, grupo, instituição e campo social. (E. D. Galery, Trad.). São Paulo: Vetor.

Berge, J. M., Loth, K., Hanson, C., Croll-Lampert, J., \& Neumark-Sztainer, D. (2011). Family life cycle transitions and the onset of eating disorders: A retrospective grounded theory approach. Journal of Clinical Nursing, 21(9-10), 1355-1363.

Bertin, I. P., \& Passos, M. C. (2003). A transmissão psíquica em debate: Breve roteiro das concepções psicanalítica e sistêmica. Interações, 8(15), 65-79.

Birmingham, C. L., Su, J., Hlynsky, J. A., Goldner, E. M., \& Gao, M. (2005). The mortality rate from anorexia nervosa. International Journal of Eating Disorders, 38(2), 143-146.

Björk, T., \& Ahlström, G. (2008). The patient's perception of having recovered from an eating disorder. Health Care for Women International, 29(8-9), 926-944.

Bogdan, R., \& Biklen, S. (1994). Investigação qualitativa em educação. Porto: Porto Editora.

Bruch, H. (1973). Eating disorder: Obesity, anorexia nervosa and person within. Nova York: Basic Books.

Brusset, B. (2008). Anorexia mental e bulimia do ponto de vista de sua gênese nervosa (M. Seincman, Trad.). In R. Urribari (Eds.) Anorexia e bulimia. São Paulo: Escuta.

Canetti, L., Kanyas, K., Lerer, B., Latzer, Y., \& Bachar, E. (2008). Anorexia nervosa and parental bonding: The contribution of parent-grandparent relationships to eating disorder psychopathology. Journal of Clinical Psychology, 64(6), 703-716.

Cao, S., Miao, S., \& Tong, J. (2013). A qualitative research on family relationships of patients with 
eating disorders. Chinese Journal of Clinical Psychology, 21(5), 703-705.

Chan, Z. C. Y., \& Ma, J. L. C. (2004). Aetiology of anorexia nervosa in Hong Kong: A social work qualitative inquiry. Child and Family Social Work, 9, 177-186.

Claudino, A. M., \& Borges, M. B. F. (2002). Critérios diagnósticos para os transtornos alimentares: Conceitos em evolução. Revista Brasileira de Psiquiatria, 24(3), 7-12.

Correa, O. B. R. (2000). O legado familiar: A tecelagem grupal da transmissão psíquica. Rio de Janeiro: Contra Capa Livraria.

Eiguer, A. (1985). Um divã para a família (L. M. V. Fisher, Trad.). Porto Alegre: Artes Médicas.

Eisenberg, M. E., Berge, J. M., Fulkerson, J. A., \& Newmark-Sztainer, D. (2012). Associations between hutful weight-related comments by family and significant other and the development of disorderd eating behaviors in young adults. Journal of Behavior Medicine, 35(5), 500-508.

Eisler, I. (1995). Family models of eating disorders. In G. Szmukler, C. Dare, \& J. Treasure (Eds.), Handbook of eating disorders: Theory, treatment and research. England: John Wiley \& Sons.

Fernandes, M. H. (2003). Corpo. São Paulo: Casa do Psicólogo.

Férnandez-Aranda, F., Krug, I., Granero, R., Ramón, J. M., Badia, A., Giménez, L., Solnao, R., Coliier, D., Karwautz, A., \& Treasure, J. (2006). Individual and family eating patterns during childhood and early adolescence: An analysis of associated eating disorder factors. Appetite, 49(2), 476-485.

Field, A. E., Javaras, K. M., Aneja, P., Kitos, N., Camargo, C. A., Taylor, B., \& Laird, N. M. (2008). Family, peer and media predictors of becoming eating desordered. Archives of Pediatrich Adolescent Medicine, 162(6), 574-579.

Fortes, I. (2011). Anorexia: O traço da obstinação na clínica psicanalítica. Revista Latinoamericana de Psicopatologia Fundamental, 14(1), 83-95.

Franko, D. L., Thompson, D., Barton, B. A., Affenito, S. G., \& Striegel-Moore, R. H. (2008). What mediates the relationship between family meals and adolescent health issues? Health Psychology, 27(2), 109-117.
Gaspar, F. L. (2005). A violência do outro na anorexia: Uma problemática de fronteiras. Revista Latinoamericana de Psicopatologia Fundamental, 8(4), 629-643.

Goulart, D. M., \& Santos, M. A. (2012). Corpo e palavra: Grupo terapêutico para pessoas com transtornos alimentares. Psicologia em Estudo (Maringá), 17(4), 607-617.

Honey, A., Clarke, S., Halse, C, Kohn, M., \& Madden, S. (2006). The influence of siblings on the experience of anorexia nervosa of adolescent girls. European Eating Disorders Review, 14, 315-322.

Kaës, R. (2001). Transmissão da vida psíquica entre gerações (C. Berliner, Trad.). São Paulo: Casa do Psicólogo.

Kaplan, M. J. (2002) Approaching sexual issues in primary care. Women's Mental Health, 29(1), 113-124.

Keery, H., Boutelle, K., Berg, P., van den, \& Thompson, J. K. (2005). The impact of appearance-related teasing by family members. Journal of Adolescent Health, 37, 120-127.

Klump, K. L., Bulik, C. M., Kaye, W. H., Trasure, J., \& Tyson, E. (2009). Academy for eating disorders position paper: Eating disorders are serious mental illnesses. International Journal of Eating Disorders, 42, $97-103$

Lane, R. C. (2002). Anorexia, masochism, self-mutilation and auto-erotism: The spider mother. Psychoanalytic Review, 89(1), 101-123.

Latzer, Y., Lavee, Y., \& Gal, S. (2009). Marital and parent child relationships in families with daughters who have eating disorders. Journal of Family Issues, 30(9), 1201-1220.

Lawrence, M. (2002). Body, mother, mind: Anorexia, femininity and the intrusive object. The International Journal of Psychoanalysis, 83(4), 837-850.

Leonidas, C., \& Santos, M. A. (2012). Imagem corporal e hábitos alimentares na anorexia nervosa: Uma revisão integrativa da literatura. Psicologia: Reflexão e Crítica, 23(3), 550-558.

Leonidas, C., \& Santos, M. A. (2013). Redes sociais significativas de mulheres com transtornos alimentares. Psicologia: Reflexão e Crítica, 26(3), 561-571.

Leonidas, C. \& Santos, M. A. (2014). Social support networks and eating disorders: An integrative review of the literature. Neuropsychiatric Disease and Treatment, 10, 915-927. doi: 10.2147/NDT.S60735 
Leonidas, C., Crepaldi, M. A., \& Santos, M. A. (2013). Bulimia nervosa: Uma articulação entre aspectos emocionais e rede de apoio social. Revista de Psicologia: Teoria e Prática, 15(2), 62-75.

Leonidas, C. \& Santos, M. A. (2015). Family relations in eating disorders: The Genogram as instrument of assessment. Ciência \& Saúde Coletiva, 20(5), 1435-1447.

Ma, J. L. C. (2005). The diagnostic and therapeutic use of family conflicts in a Chinese context: The case of anorexia nervosa. Journal of Family Therapy, 27(1), 24-42.

Ma, J. L. C. (2008). Eating disorders, parent-child conflicts, and family therapy un Shenzhen, China. Qualitative Health Research, 18(6), 803-810.

Marcos, Y. Q., \& Cantero, M. C. T. (2009). Assesment of social support dimensions in patients with eating disorders. The Spanish Journal of Psychology, 12(1), 226-235.

Miranda, M. R. (2007). Em busca das palavras perdidas: O corpo, carcereiro da mente, nos distúrbios alimentares. Ide, 30(45), 28-34.

Miranda, M. R. (2011). A complexidade da relação mãefilha nas patologias dos contrários. In C. A. N. B. Bruno (Ed.), Distúrbios alimentares: Uma contribuição da psicanálise (p. 123-154). Rio de Janeiro: Imago.

Morgan, C. M., \& Claudino, A. M. (2005). Epidemiologia e etiologia. In A. M. Claudino, \& M. T. Zanella (Eds.), Guia de medicina ambulatorial e hospitalar / UNIFESP-EPM: Transtornos alimentares e obesidade. São Paulo: Manole.

Nilsson, K. Abrahamsson, K. Torbiornsson, A., \& Hägglöff, B. (2009). Causes of adolescent onset anorexia nervosa: Patient perspectives. Eating Disorders, 15, 125-133.

Noordenbos, G., \& Seubring, A. (2006). Criteria for recovery from eating disorders according to patients and therapists. Eating Disorders, 14(1), 14-54.

Oliveira-Cardoso, E. A., \& Santos, M. A. (2012). Avaliação psicológica de pacientes com anorexia e bulimia nervosas: Indicadores do Método de Rorschach. Fractal: Revista de Psicologia [online], 24(1), 159-174. Retrieved from http://www.scielo.br/ $\mathrm{pdf} /$ fractal/v24n1/v24n1a11.pdf

Oliveira-Cardoso, E., Von Zuben, B. V., \& Santos, M. A. (2014). Quality of life of patients with anorexia and bulimia nervosa. Demetra: Food, Nutrition and Health, 9(Supl.1), 329-340.

Oliveira, L. L., \& Hutz, C. S. (2008). Padrões de interação em famílias de adolescentes com anorexia nervosa restritiva e bulímica: Semelhanças e diferenças. Estudos e Pesquisas em Psicologia, 8(3), 712-743.

Onnis, L., Giannuzzi, M., \& Romano, C. (2007). Un vide à combler: Anorexie et boulimie dans une perspective transgénérationnelle. Cabiers Critiques de Thérapie Familial et de Pratiques de Réseaux, 1(38), 135-157.

Peres, R. S., \& Santos, M. A. (2011). Técnicas projetivas na avaliação de aspectos psicopatológicos da anorexia e bulimia. PsicoUSF, 16(2), 185-192.

Perkins, P. S., Slane, J. D., \& Klump, K. L. (2013). Personality clusters and family relationships in women with disordered eating symptoms. Eating Behaviors, 14(3), 299-308.

Ribeiro, M. F. R. (2011). De mãe em filha: A transmissão da feminilidade. São Paulo: Escuta.

Ribeiro, R. P. P., \& Santos, M. A. (2013). Transtornos alimentares: Evidências clínicas e científicas. In S. S. Almeida, T. M. B. Costa, M. F. Laus, \& G. Straatmann (Eds.), Psicobiologia do comportamento alimentar (pp. 175-196). Rio de Janeiro: Rubio.

Rosa, B. P., \& Santos, M. A. (2011). Comorbidade entre bulimia nervosa e transtorno de personalidade borderline: Implicações para o tratamento. Revista de Psicopatologia Fundamental, 14(2), 268-282.

Scorsolini-Comin, F., \& Santos, M. A. (2012). Psicoterapia como estratégia de tratamento dos transtornos alimentares: Análise crítica do conhecimento produzido. Estudos de Psicologia (Campinas), 29(Suplemento), 851-863.

Soifer, R. (1980). Psicodinamismos de la familia con niños. Buenos Aires: Editorial Paidos.

Souza, L. V., \& Santos, M. A. (2012). Familiares de pessoas diagnosticadas com transtornos alimentares: Participação em atendimento grupal. Psicologia: Teoria e Pesquisa, 28(3), 325-334.

Souza, L. V. \& Santos, M. A. (2013a). Quem é o especialista? Lugares ocupados por profissionais e pacientes no tratamento dos transtornos alimentares. Estudos de Psicologia (Natal), 18(2), 259-267.

Souza, L. V. \& Santos, M. A. (2013b). Proximidade afetiva no relacionamento profissional-paciente no 
tratamento dos transtornos alimentares. Psicologia em Estudo (Maringá), 18(3), 395-404.

Stake, R. E. (2000). Case studies. In N. K. Denzin, \& Y. S. Lincoln (Eds.), Handbook of qualitative research (pp. 435-454). London: Sage.

Tuval-Mashiach, R., Hasson-Ohayon, I., \& Ilan, A. (2014). Attacks on linking: Stressors and identity challenges for mothers of daughters with long lasting anorexia nervosa. Psychology and Health, 29(6), 613-631.

Wagner, A. (2004). Introdução. In Wagner, A. (Eds.), Como se perpetua a família? A transmissão dos modelos familiares. Porto Alegre: EDIPUCRS.

Wagner, A., \& Falcke, D. (2004). A dinâmica familiar e o fenômeno da transgeracionalidade: Definição de conceitos. In A. Wagner (Ed.), Como se perpetua a familia? A transmissão dos modelos familiares. Porto Alegre: EDIPUCRS.
Valdanha, E. D., Scorsolini-Comin, F., Peres, R. S., \& Santos, M. A. (2013). Influência familiar na anorexia nervosa: Em busca das melhores evidências científicas. Jornal Brasileiro de Psiquiatria, 62(3), 225-233.

Valdanha, E. D., Oliveira-Cardoso, E. A., Ribeiro, R. P. P., Miasso, A. I. Pilon, S. C. \& Santos, M. A. (2014). A arte de nutrir vínculos: Psicoterapia de grupo nos transtornos alimentares. Revista da SPAGESP, (15)2, 94-108.

Valdanha, E. D., Scorsolini-Comin, F., \& Santos, M. A. (2013). Anorexia nervosa e transmissão psíquica transgeracional. Revista Latinoamericana de Psicopatologia Fundamental, 16(1), 71-88.

Yin, R. K. (2005). Estudo de caso: Planejamento e métodos (D. Grassi, Trad.). Porto Alegre: Bookman.

Recebido 25/08/2015

Reformulado 08/10/2015

Aceito 27/10/2015 
Nota dos autores:

Apoio: CAPES

Sobre os autores:

Élide Dezoti Valdanha-Ornelas é psicóloga, doutoranda pelo Programa de Pós-graduação em Psicologia da Faculdade de Filosofia, Ciências e Letras de Ribeirão Preto da Universidade de São Paulo (FFCLRP-USP) e pela École Doctorale Recherches en Psychanalyse et Psychopathologie da Université Paris-Diderot (Paris VII), bolsista de doutorado da Fundação de Amparo à Pesquisa do Estado de São Paulo (FAPESP), membro do Laboratório de Ensino e Pesquisa em Psicologia da Saúde (LEPPS-USP-CNPq) e psicóloga do Grupo de Assistência em Transtornos Alimentares - GRATA.

E-mail: elidevaldanha@usp.br

Manoel Antônio dos Santos é Professor Associado 3 do Programa de Pós-Graduação em Psicologia da Faculdade de Filosofia, Ciências e Letras de Ribeirão Preto da Universidade de São Paulo (FFCLRP-USP), líder do Laboratório de Ensino e Pesquisa em Psicologia da Saúde (LEPPS-USP-CNPq) e bolsista de Produtividade em Pesquisa do CNPq nível 1B.

E-mail:manoelmasantos@gmail.com

Contato com os autores:

Departamento de Psicologia, Bloco 5, sala 34 da Faculdade de Filosofia, Ciências e Letras de Ribeirão Preto da Universidade de São Paulo

Av. Bandeirantes, 3900

CEP: $14040-901$

Monte Alegre - Ribeirão Preto-SP, Brasil

Telefone: (16) 3315-3645

Faculdade de Filosofia, Ciências e Letras de Ribeirão Preto

Universidade de São Paulo

Laboratório de Ensino e Pesquisa em Psicologia da Saúde - LEPPS

Psico-USF, Bragança Paulista, v. 21, n. 3, p. 635-649, set./ deæ. 2016 